\title{
Explaining the intention of dental health personnel to report suspected child maltreatment using a reasoned action approach
}

Ingfrid Vaksdal Brattabø $\varnothing^{1,2^{*}}$ (D), Ragnhild Bjørknes ${ }^{2}, K_{\text {Krre Breivik }}^{4}$ and Anne Nordrehaug Åstrøm ${ }^{1,3}$

\begin{abstract}
Background: This study provides an empirical test of the reasoned action approach (RAA) socio-cognitive theory with the aim of 1) predicting the intention of public dental health personnel (PDHP) to report suspected child-maltreatment to child welfare services (CWS); 2) estimating the effects of the theoretical constructs of RAA, including experiential and instrumental attitudes, injunctive and descriptive norms, and perceived capacity and autonomy regarding PDHP's behavioural intentions; and 3) exploring whether the RAA operates equivalently (i.e., is invariant) in male and female providers.
\end{abstract}

Methods: This national cross-sectional study was conducted in Norway. An electronic survey was distributed to 1542 dentists and dental hygienists working in the public dental health service. The survey included RAA items constructed in accordance with the recommendations for the RAA model. Structural equation modelling (SEM) was used to identify factors derived from the theory of RAA to predict PDHP reporting intentions.

Results: A total of $77.8 \%$ (1200) of those surveyed responded to the survey. The present study provided support for the utility of the RAA across both male and female providers in predicting their intention to report suspected child-maltreatment to the CWS. The final modified SEM model revealed that instrumental attitudes and perceived behavioural control (based on merged capacity and autonomy parameters) were the strongest predictors of intention to report, followed by the reporting of descriptive norms, injunctive norms and experiential attitudes. These factors explained $63.6 \%$ of the observed variance in the reporting intention.

Conclusions: The large amount of explained variance suggests that RAA is a well-functioning theory that predicts PDHP's reporting intentions to CWS across gender, and gives an understanding of the socio-cognitive factors involved. To strengthen reporting intention among dental personnel, this study suggests educators should focus on the value and positive consequences of reporting, the resources available and how to overcome obstacles; attention to normative expectations and individuals' feelings about reporting may also be helpful.

Keywords: Child maltreatment, Child abuse, Child welfare services, Dental auxiliaries, Mandatory reporting, Oral health, Reasoned action approach, Structural equation modelling

\footnotetext{
* Correspondence: ingfrid.brattabo@hfk.no

'Oral Health Centre of Expertise in Western Norway, Hordaland, Pb. 2354

Møllendal, 5867 Bergen, Norway

${ }^{2}$ Department of Health Promotion and Development, Faculty of Psychology,

University of Bergen, $\mathrm{Pb}$. 7807, 5020 Bergen, Norway

Full list of author information is available at the end of the article
}

(c) The Author(s). 2019 Open Access This article is distributed under the terms of the Creative Commons Attribution 4.0 International License (http://creativecommons.org/licenses/by/4.0/), which permits unrestricted use, distribution, and reproduction in any medium, provided you give appropriate credit to the original author(s) and the source, provide a link to the Creative Commons license, and indicate if changes were made. The Creative Commons Public Domain Dedication waiver (http://creativecommons.org/publicdomain/zero/1.0/) applies to the data made available in this article, unless otherwise stated. 


\section{Background}

Victims of child maltreatment have an augmented risk for major psychiatric and medical disorders [1-5]. The scope and severity of these disorders are likely to increase with the duration and severity of maltreatment. For this reason, the early detection of victimized children is an important objective worldwide [6-9]. In Norway, public dental health personnel (PDHP) are mandated through the Norwegian Health Personnel Act, $\$ 33$, to report to the child welfare service (CWS) when there is reason to believe that a child is or will be abused, subjected to serious deficiencies in daily care or other serious neglect.

This obligation goes above and beyond health personnel's duty of confidentiality $\$ 21$. [10]. Failure to fulfil the Norwegian Health Personnel Act, $\mathbb{S} 33$, can result in administrative reactions from the Norwegian Board of Health Supervision. As in the other Nordic countries, Norwegian children are offered free dental service at public dental health service (PDHS) locations throughout their childhood and adolescence (0-18 years) [11]. With a dental attendance rate close to $100 \%$, the Norwegian PDHP meets most children and adolescents on a regular basis, making the PDHS an important arena for the detection of child maltreatment. Statistics Norway reports that the CWS in Norway received 58 580 reports of concern in 2017, of which 768 came from the PDHS [12]. According to a Norwegian national study, $60 \%$ of PDHP reported to have sent at least one report of concern to the CWS during their career [13]. In regard to PDHP's reporting frequency throughout career, adjusted analysis revealed no significant differences in incidence rate ratio between dentists and dental hygienists or across age groups, while females were less likely to report to CWS than males. Further, PDHP working in municipalities with 10.000 or less inhabitants were less likely to report than their colleagues working in larger municipalities. [13]. While most reports of concern to CWS from PDHS relate to oral conditions, failure to attend and not being brought to dental appointments, reports of concern are also sent due to suspicion of neglect, physical, psychological and sexual abuse [14]. Dental personnel suspect and identify a variety of child maltreatments [14]. The awareness and knowledge regarding detection of child maltreatment and the role of dental personnel has increased in recent years. As a consequence a new paragraph $\mathbb{\$} 1$-3c was added to the Norwegian Dental Health Service Act in 2018, stating that the PDHS should be able to prevent, detect and avert violence and sexual abuse [11].

Yet, underreporting of suspected child maltreatment is a challenge among dental health personnel world-wide [13, 15-20]. The national study among PDHP in Norway revealed that $32 \%$ of the dental health personnel investigated failed to report suspected child maltreatment to the CWS one or several times during their career [13]. Such findings are consistent with those from other countries and imply that steps should be taken to strengthen the reporting accuracy of suspected child maltreatment $[15,16,19-22]$. Underreporting of child maltreatment can have major consequences for the child, its family and the society at large. The gap between suspicion of child maltreatment and reporting to CWS needs to be closed. Hence, there is a need to understand which factors that inhibit and promote dental personnel's reporting. The effective promotion of mandatory reporting obligations in the PDHS may require a thorough understanding of the socio-cognitive factors underlying the decision of dental health personnel to report suspected maltreatment to the CWS. Previous studies have identified reporting barriers among dental health personnel, such as uncertainty regarding their observations and signs of child maltreatment, lack of knowledge regarding reporting procedures, and fear of consequences to child and dental personnel [15, 19-21]. However, in spite of their importance, socio-cognitive factors have not been sufficiently investigated. While conceptual frameworks have been used to examine reporting of child maltreatment among teachers and nurses [23-25], to our knowledge, no theory driven studies have been conducted for dental health personnel. A socio-cognitive model that adequately explains variance in intended reporting of suspected child maltreatment to the CWS could be an important tool in order to develop an effective behaviour change program for dental health personnel. Although such a sociocognitive model has yet to be validated among dental health personnel.

A socio cognitive model of the attitude - behaviour relationship, the theory of planned behaviour (TPB) [26] has been applied across various study populations, and behavioural domains to predict intention and subsequent behaviour [27-30]. According to the TPB, behavioural intention is the immediate predictor of actual behaviour [31, 32]. Intention, in turn, is predicted by attitudes, subjective norms and perceived behavioural control (PBC). Attitudes reflect a favourable or unfavourable evaluation of a particular behaviour. Subjective norms refer to perceived social pressures to perform a given behaviour, and perceived behavioural control reflect the perceived ease or difficulty associated with performing a particular behaviour. Finally, attitudes, subjective norms and perceived behavioural control are underpinned by behavioural, normative and control beliefs, respectively [26]. The TPB hypothesizes that attitudes, subjective norms and perceived behavioural control influence the behaviour indirectly through behavioural intentions and that perceived behavioural control influences behaviour directly whenever the behaviour is not under complete 
volitional control [33]. There is considerable empirical support for the TPB across various health related behaviours, including health screening behaviours [26, 27]. Two meta-analyses have revealed that, overall, the TPB explains between 39 and $44.3 \%$ and $19.3-27 \%$ of the variance in intention and subsequent behaviour, respectively $[27,34]$.

Many studies have argued that attitudes, subjective norms and perceived behavioural control reflect separate binary subcomponents, as shown in Fig. 1 [35-37]. This conceptual development of the TPB is variously referred to as an augmented TPB model, a two-factor model, and the reasoned action approach (RAA) [35, 38-41]. The RAA suggests that: Attitude consist of the subcomponents experiential (i.e., affective component of attitude) and instrumental (i.e., cognitive component of attitude) attitudes. Perceived norm consists of the subcomponents injunctive (i.e., the perceived social approval of others) and descriptive norms (i.e., perceptions of what others do). Perceived behavioural control consists of the subcomponents capacity to perform the behaviour (based on the ease or difficulty of the behaviour) and autonomy (their perception of their control over the behaviour). According to the RAA, intention is the immediate predictor of behaviour, whereas each attitudinal, normative and control sub-component predicts intention directly. In addition, capacity and autonomy predicts behaviour directly when the behaviour is not under volitional control $[41,42]$. Moreover, the RAA predicts that the relative importance of the theoretical constructs on behavioural intention may vary across various behaviours and groups of participants. See Fig. 1 for details of the original RAA model. Thus, the RAA provides a unique opportunity to identify the relative importance of each specific subcomponent (i.e. experiential and instrumental attitude, injunctive and descriptive norm, capacity and autonomy) as predictors of intention and behaviour. The RAA has received empirical support across risk and protective health related behaviours. A meta-analysis covering risk behaviours like smoking and taking illegal drugs, protective behaviours like physical activity and dieting, and a range of different health related behaviours like health screening and blood donating revealed that the RAA explained 58.7 and $32.3 \%$ of the variance in intention and behaviour, respectively [41]. Moreover, experiential and instrumental attitudes and capacities were found to be the strongest predictors of intention, while injunctive and descriptive norms were more modest predictors [41]. Few studies have focused on health and dental health personnel's professional behaviour using a socio-cognitive approach [43-47]. It seems worthwhile to investigate whether the predictive utility of the RAA can be generalized to dental health personnel's intention to report child maltreatment in the primary dental health care setting. Further, Brattabø et al. [13], found no significant differences between males and females, in regard to dental personnel's incidence rate ratio for reporting to CWS in recent years (2012-2014), while the incidence rate ratio for reporting throughout career was significant lower for females compared to men [13]. Due to this it is also important to assess whether the RAA operates equivalently (i.e., is invariant) across males and females.

This study provides an empirical test of the RAA with the aim of 1) predicting the intention of PDHP to report suspected child maltreatment to CWS; 2) estimating the effects of the theoretical constructs of RAA, including experiential and instrumental attitudes, injunctive and descriptive norms, and perceived capacity and autonomy regarding PDHP's reporting intentions; and 3) exploring whether the RAA operates equivalently (i.e., is invariant) in male and female providers.

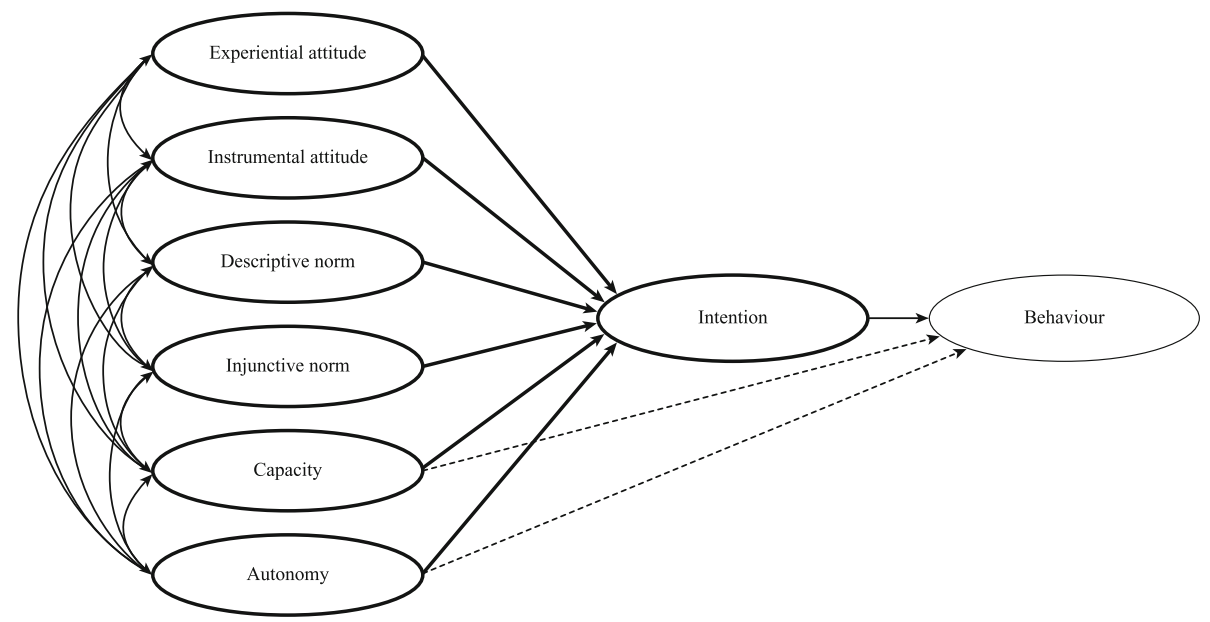

Fig. 1 Original RAA model. The bold parts show the hypothesized model measured in this study 
Consistent with the conceptualization of the RAA [38], we hypothesized that a model with the following characteristics would fit the variables measuring experiential (i.e., affective component of attitude) and instrumental (i.e., cognitive component of attitude) attitudes, injunctive (i.e., the perceived social approval of others) and descriptive (i.e., perceptions of what others do) norms, capacity (i.e. the ease or difficulty to perform the behaviour) and autonomy (i.e., their perception of their control over the behaviour) and intention (i.e., to report suspected child maltreatment); the model would include seven factors corresponding to the measuring items used in scoring each theoretical construct.

\section{Methods}

A census of all the registered public dentists and dental hygienists employed in the PDHS in 18 of the 19 counties in Norway were asked to take part in a national cross-sectional study. The last county was not included, as it was used in the pilot study. The names and contact information of the dental professionals were collected from the chiefs of the Norwegian PDHS's, who also allowed the survey to be administered during business hours. The study's objectives and a link to an electronic questionnaire, containing an informed consent page, were sent by electronic mail to all the registered public dentists and dental hygienists a total of 1542 dentists and dental hygienists. The estimated completion time of the survey was $30-40 \mathrm{~min}$ (The questionnaire is available as Additional file 1). The survey was approved and registered by the Ombudsman of the Norwegian Social Science Data Services (NSD) (Reference number: 40581/4/LH/LR) who administered the questionnaire distribution and data collection, in November 2014. Non-responders were given reminders after two, four and seven weeks.

The questionnaire was developed in three stages to ensure that the instrument was well suited to the Norwegian public dental health context. First, the semantics and content of the questions were assessed, and the questions were translated and back translated from Norwegian to English. Second, PDHP with experience in survey research and clinical work reviewed the questionnaire. Third, a pilot study in one county $(n=176)$ was conducted.

The questionnaire incorporated each theoretical construct of the RAA model in terms of the experiential and instrumental attitudes, injunctive and descriptive norms, and the capacity and autonomy and intention assessed in relation to the likelihood of reporting suspected child abuse or neglect in the following 12-month period. The questions related to each theoretical construct of the RAA were constructed in accordance with the principle of compatibility and based on recommendations for the reasoned action approach model proposed by Ajzen and Fishbein in 2010 [38]. In line with the recommendations that each predictor should be self-referent and measured at the same specificity as the target behaviour, the elements of the target (reporting suspected child maltreatment), the action (sending a report of concern to CWS), the context (the public dental health service) and the time (during the next 12 months) were considered [38]. Experiential attitude (i.e., tapping affective aspects of behavioural beliefs) and instrumental attitude (i.e., tapping cognitive aspects of behavioural beliefs), capacity (i.e., based on the ease or difficulty to report suspected child maltreatment) and autonomy (i.e., their perception of their control in regard to report suspected child maltreatment) and intention to report suspected child maltreatment were each measured by four items. Injunctive norm (i.e., the perceived social approval of others in regard to report suspected child maltreatment) and descriptive norm (i.e., perceptions of what others do when they suspect child maltreatment), were measured by five items each, giving a total of 30 items, see Table 2. Responses were provided on five point Likert scales (with possible responses ranging from 1 to 5), with varying response options (i.e., quite unlikely/quite likely, very difficult/very easy, totally disagree/ totally agree).Respondents' previous experience with suspecting and reporting child maltreatment was assessed along with their demographical characteristics, including gender, age, occupation, years of working experience in the PDHS, number of patients treated last 12 months, county and size of municipality where dental clinic was located. Additional information regarding the DPHP reporting experience can be found in Brattabø et al. 2016 [13].

\section{Statistics}

The Statistical Package for Social Sciences version 22 (SPSS Inc., Chicago, IL, USA) was used for descriptive statistics in terms of frequency \% (n) and mean (SD) distributions. Mplus version 7.4 (Muthen \& Muthen 1998-2015) was used to test the structural equation models (SEM).

The original hypothesized RAA model (See Fig. 1, in bold) was tested using a two-step modelling approach (Kline, 2011). In the first step, the hypothesized RAA model was re-specified as a correlated factor model to test the adequacy of the measurement model. In the second step, a full structural regression model was conducted to test the plausibility of the postulated RAA model (including potential modifications based on the findings detailed in step 1). Modification indices were used to test for sources of misfit. Multiple group analyses were used in both steps to test for invariance across gender. A prerequisite for exploring whether the predictive paths are gender invariant (step 2) is that the 
measurement model (step 1) is both configural (equal form) and metric invariant (equal factor loadings) across men and women [48]. Configural invariance was examined by testing the fit of the measurement model separately for women and men. When testing for metric invariance, the fit of the models for which the loadings on each specific factor were held equal between genders was compared to a baseline 2-group configural model in which the same parameters (except for the identification items) were free to vary. The model was assumed to be non-invariant if the change in the chi- square was significant (as tested by changes in Satorra-Bentler scaled $X 2$ [49]) and the decrease in CFI was larger than 0.002 [50] compared to the baseline model.

The maximum likelihood estimator with robust standard errors (MLR) was used to take into account the non-normally distributed data. To measure how well the model fit the sample data, the overall goodness of fit was assessed by the Chi-square test $\left(\mathrm{x}^{2}\right)$, the standardized root mean squared residual (SRMR), the root mean square error of approximation (RMSEA) and the comparative fit index (CFI). A good fit between the measurement model and the data is indicated by a Chi square test with a statistically insignificant result at the $p<0.05$ threshold. However, as the Chi-square test is highly dependent on the sample size, it is possible to detect trivial problems in large samples. We therefore put more emphasis on the alternative fit indices when judging the model fit. An acceptable and good fit is indicated by an SRMR $<0.08$ and $<0.05$, an RMSEA $<0.08$ and $<0.06$ and $a \mathrm{CFI}>0.90$ and $>0.95[51,52]$.

Regarding missing data, 17 of the 1200 cases had missing on all included variables and were therefore excluded. The sample size varied between 1183 and 1113 (see Tables 1 and 2). The MLR estimators, including full

Table 1 Frequency distribution \% (n) characteristics of the studied public dental health personnel

\begin{tabular}{|c|c|c|c|c|}
\hline Characteristics & Categories & Dentists & Dental hygienists & Total \\
\hline \multirow[t]{3}{*}{ Gender } & & $\%(n)$ & $\%(n)$ & $\%(n)$ \\
\hline & Female & $72.1(554)$ & $98.6(341)$ & $80.3(895)$ \\
\hline & Male & $27.9(214)$ & $1.4(5)$ & $19.7(219)$ \\
\hline \multicolumn{5}{|l|}{ Age } \\
\hline & 20-39years & $57.3(440)$ & $41.6(144)$ & $52.4(584)$ \\
\hline & $40+$ years & $42.7(328)$ & $58.4(202)$ & $47.6(530)$ \\
\hline \multicolumn{5}{|c|}{ Working experience at PDHS } \\
\hline & $1-10$ years & $66.0(507)$ & $45.4(157)$ & $59.6(664)$ \\
\hline & $11+$ years & $34.0(261)$ & $54.6(189)$ & $40.4(450)$ \\
\hline \multicolumn{5}{|c|}{ Number of patients $<19$ years.* } \\
\hline & $0-500$ & $47.4(364)$ & $24.1(83)$ & $40.2(447)$ \\
\hline & $501-+$ & $52.6(404)$ & $75.9(262)$ & $59.8(666)$ \\
\hline
\end{tabular}

* last 12 months information maximum likelihood (FIMLs), were used to handle the remaining missing data [53]. This is the default method for handling missing when using the maximum likelihood estimator in Mplus 7.4 and is generally superior to standard ad hoc missing data routines such as the mean replacement, pairwise deletion and listwise deletion [54].

\section{Results}

A total of 1200 of the eligible 1542 (RR 77.8\%) dentists and dental hygienists responded to our survey. In accordance with gender and professional distribution in the Norwegian PDHS, 19.7 and $80.3 \%$ of the respondents were men and women, respectively, while $31.1 \%$ were dental hygienists and $68.9 \%$ were dentists. Among the respondents, $82.9 \%$ had examined more than 250 children and adolescents < 19 years of age during the previous 12 months. The mean working experience of the respondents was $11.9(\mathrm{SD}=11.2)$ years (Table 1$)$.

Throughout their career, $32.6 \%$ of the respondents had failed to report suspected child abuse or neglect, with a mean of 2.3 (SD =1.8) failures. In contrast, $60 \%$ of the respondents were experienced reporters, having sent at least one reports of concern, with a mean of $3.6(\mathrm{SD}=3.4))$ reports [13].

Table 2 shows the descriptive statistics for each of the 30 items measuring the RAA constructs in terms of mean, standard deviation and skewness. The range for the items was between 1 and 5 , with low values indicating negative or weak cognitions and high values indicating positive or strong cognitions. As shown in Table 2, while items 1-4 (experiential attitude) had mean values $<2.8$, item 5-30 (instrumental attitudes, descriptive and injunctive norm and capacity and autonomy) all had mean values $>3.5$.

\section{Step 1. Measurement model}

The initially proposed correlated seven-factor model (Model 1) (experiential and instrumental attitude, injunctive and descriptive norm, capacity and autonomy and intention) lacked an adequate fit to the data on most fit indices employed, see Table 3. The analysis further revealed that the capacity and autonomy factors were very highly correlated (standardized correlation coefficient $=0.839$, $\mathrm{SE}=0.051, P<0.001)$, at above 0.800 and close to the cut off measure of 0.850 , indicating poor discriminant validity between the two latent variables [55]. In addition, preliminary analysis showed that multicollinearity would lead to inflated standard errors in the paths in the full structural equation model [56]. The capacity and autonomy factors were therefore merged into one latent factor, labelled perceived behavioural control, including 8 indicators (item 19-26), reducing the number of latent factors in the measurement model from seven to six. Merging these two 
Table 2 Descriptive statistics for RAA measurement model

\begin{tabular}{|c|c|c|c|c|c|c|c|c|c|c|c|}
\hline \multirow[t]{2}{*}{ Latent factor } & \multirow[t]{2}{*}{ Item } & \multirow[t]{2}{*}{$\mathrm{N}$} & \multirow[t]{2}{*}{ Question } & \multirow{2}{*}{$\begin{array}{l}\text { Answers } \\
\text { Valued 1-5 (very } \\
\text { difficult = } 1 \text { - very } \\
\text { easy = 5) }\end{array}$} & \multirow{2}{*}{$\begin{array}{l}\text { Cronb. } \\
\text { alpha }\end{array}$} & \multicolumn{2}{|l|}{ Mean } & \multicolumn{2}{|c|}{ Skewness } & \multicolumn{2}{|l|}{ Kurtosis } \\
\hline & & & & & & Statistic & $\begin{array}{l}\text { Std. } \\
\text { dev }\end{array}$ & Statistic & Std.error & Statistic & Std.error \\
\hline \multirow[t]{4}{*}{$\begin{array}{l}\text { Experiential } \\
\text { attitude }\end{array}$} & 1 & 1183 & $\begin{array}{l}\text { To send a report of } \\
\text { concern on suspicion of } \\
\text { child abuse or neglect } \\
\text { the following } 12 \\
\text { months is }\end{array}$ & $\begin{array}{l}\text { very difficult, difficult, } \\
\text { neither/nor, easy, very } \\
\text { easy }\end{array}$ & .814 & 2.64 & .884 & .538 & .071 & .180 & .142 \\
\hline & 2 & 1181 & $\begin{array}{l}\text { To send a report of } \\
\text { concern on suspicion of } \\
\text { child abuse or neglect } \\
\text { the following } 12 \\
\text { months is }\end{array}$ & $\begin{array}{l}\text { very onerous, onerous, } \\
\text { neither/nor, simple, very } \\
\text { simple }\end{array}$ & & 2.72 & .770 & .504 & .071 & .324 & .142 \\
\hline & 3 & 1183 & $\begin{array}{l}\text { To send a report of } \\
\text { concern on suspicion of } \\
\text { child abuse or neglect } \\
\text { the following } 12 \\
\text { months is }\end{array}$ & $\begin{array}{l}\text { very unpleasant, } \\
\text { unpleasant, neither/nor, } \\
\text { pleasant, very pleasant }\end{array}$ & & 2.33 & .649 & .309 & .071 & .657 & .142 \\
\hline & 4 & 1183 & $\begin{array}{l}\text { To send a report of } \\
\text { concern on suspicion of } \\
\text { child abuse or neglect } \\
\text { the following } 12 \\
\text { months is }\end{array}$ & $\begin{array}{l}\text { very demanding, } \\
\text { demanding, neither/ } \\
\text { nor, no problem, } \\
\text { absolutely no problem }\end{array}$ & & 2.52 & .749 & .556 & .071 & .506 & .142 \\
\hline \multirow[t]{4}{*}{$\begin{array}{l}\text { Instrumental } \\
\text { attitude }\end{array}$} & 5 & 1183 & $\begin{array}{l}\text { To send a report of } \\
\text { concern on suspicion of } \\
\text { child abuse or neglect } \\
\text { the following } 12 \\
\text { months is }\end{array}$ & $\begin{array}{l}\text { totally unimportant, } \\
\text { unimportant, neither/ } \\
\text { nor, important, very } \\
\text { important }\end{array}$ & .825 & 4.72 & .495 & -1.851 & .071 & 5.586 & .142 \\
\hline & 6 & 1183 & $\begin{array}{l}\text { To send a report of } \\
\text { concern on suspicion of } \\
\text { child abuse or neglect } \\
\text { the following } 12 \\
\text { months is }\end{array}$ & $\begin{array}{l}\text { completely useless, } \\
\text { useless, neither/nor, } \\
\text { useful, very useful }\end{array}$ & & 4.44 & .585 & -.547 & .071 & -.346 & .142 \\
\hline & 7 & 1183 & $\begin{array}{l}\text { To send a report of } \\
\text { concern on suspicion of } \\
\text { child abuse or neglect } \\
\text { the following } 12 \\
\text { months is }\end{array}$ & $\begin{array}{l}\text { totally wrong, wrong, } \\
\text { neither/nor, right, } \\
\text { completely right }\end{array}$ & & 4.66 & .506 & -1.050 & .071 & .147 & .142 \\
\hline & 8 & 1181 & $\begin{array}{l}\text { To send a report of } \\
\text { concern on suspicion of } \\
\text { child abuse or neglect } \\
\text { the following } 12 \\
\text { months is }\end{array}$ & $\begin{array}{l}\text { very unwise, unwise, } \\
\text { neither/nor, wise, very } \\
\text { wise }\end{array}$ & & 4.40 & .634 & -.670 & .071 & .072 & .142 \\
\hline \multirow[t]{4}{*}{ Descriptive norm } & & & $\begin{array}{l}\text { The following persons } \\
\text { do always send a report } \\
\text { of concern on suspicion } \\
\text { of child abuse or } \\
\text { neglect }\end{array}$ & & & & & & & & \\
\hline & 9 & 1166 & $\begin{array}{l}\text { my colleagues at the } \\
\text { dental clinic }\end{array}$ & $\begin{array}{l}\text { totally disagree, } \\
\text { disagree, neither/nor, } \\
\text { agree, totally agree }\end{array}$ & .903 & 3.66 & .894 & -.411 & .072 & .038 & .143 \\
\hline & 10 & 1165 & $\begin{array}{l}\text { my boss at the dental } \\
\text { clinic }\end{array}$ & $\begin{array}{l}\text { totally disagree, } \\
\text { disagree, neither/nor, } \\
\text { agree, totally agree }\end{array}$ & & 3.71 & .906 & -.432 & .072 & .130 & .143 \\
\hline & 11 & 1165 & $\begin{array}{l}\text { most persons in my } \\
\text { situation }\end{array}$ & $\begin{array}{l}\text { totally disagree, } \\
\text { disagree, neither/nor, }\end{array}$ & & 3.62 & .799 & -.219 & .072 & .031 & .143 \\
\hline
\end{tabular}


Table 2 Descriptive statistics for RAA measurement model (Continued)

\begin{tabular}{|c|c|c|c|c|c|c|c|c|c|c|c|}
\hline \multirow[t]{2}{*}{ Latent factor } & \multirow[t]{2}{*}{ Item } & \multirow[t]{2}{*}{$\mathrm{N}$} & \multirow[t]{2}{*}{ Question } & \multirow{2}{*}{$\begin{array}{l}\text { Answers } \\
\text { Valued } 1-5 \text { (very } \\
\text { difficult = } 1 \text { - very } \\
\text { easy = 5) }\end{array}$} & \multirow{2}{*}{$\begin{array}{l}\text { Cronb. } \\
\text { alpha }\end{array}$} & \multicolumn{2}{|l|}{ Mean } & \multicolumn{2}{|c|}{ Skewness } & \multicolumn{2}{|l|}{ Kurtosis } \\
\hline & & & & & & Statistic & $\begin{array}{l}\text { Std. } \\
\text { dev }\end{array}$ & Statistic & Std.error & Statistic & Std.error \\
\hline & 12 & 1165 & $\begin{array}{l}\text { most people who are } \\
\text { important to me }\end{array}$ & $\begin{array}{l}\text { totally disagree, } \\
\text { disagree, neither/nor, } \\
\text { agree, totally agree }\end{array}$ & & 3.57 & .801 & -.061 & .072 & .040 & .143 \\
\hline & 13 & 1165 & most persons like me & $\begin{array}{l}\text { totally disagree, } \\
\text { disagree, neither/nor, } \\
\text { agree, totally agree }\end{array}$ & & 3.67 & .789 & -.143 & .072 & .028 & .143 \\
\hline \multirow[t]{6}{*}{ Injunctive norm } & & & $\begin{array}{l}\text { If I during the coming } \\
12 \text { months suspects } \\
\text { child abuse or neglect }\end{array}$ & & & & & & & & \\
\hline & 14 & 1168 & $\begin{array}{l}\text { do my colleagues at } \\
\text { the dental clinic think } \\
\text { that I should send a } \\
\text { report of concern }\end{array}$ & $\begin{array}{l}\text { totally disagree, } \\
\text { disagree, neither/nor, } \\
\text { agree, totally agree }\end{array}$ & .921 & 4,32 & .765 & -1.438 & .072 & 3.327 & .143 \\
\hline & 15 & 1167 & $\begin{array}{l}\text { does my boss at the } \\
\text { dental clinic think that I } \\
\text { should send a report of } \\
\text { concern }\end{array}$ & $\begin{array}{l}\text { totally disagree, } \\
\text { disagree, neither/nor, } \\
\text { agree, totally agree }\end{array}$ & & 4.38 & .742 & -1.418 & .072 & 3.126 & .143 \\
\hline & 16 & 1167 & $\begin{array}{l}\text { does the public dental } \\
\text { leader group at the } \\
\text { county level think that I } \\
\text { should send a report of } \\
\text { concern }\end{array}$ & $\begin{array}{l}\text { totally disagree, } \\
\text { disagree, neither/nor, } \\
\text { agree, totally agree }\end{array}$ & & 4.36 & .784 & -1.489 & .072 & 3.163 & .143 \\
\hline & 17 & 1167 & $\begin{array}{l}\text { most persons important } \\
\text { to me think that I } \\
\text { should send a report of } \\
\text { concern }\end{array}$ & $\begin{array}{l}\text { totally disagree, } \\
\text { disagree, neither/nor, } \\
\text { agree, totally agree }\end{array}$ & & 4.30 & .773 & -1.265 & .072 & 2.456 & .143 \\
\hline & 18 & 1168 & $\begin{array}{l}\text { is it expected of me } \\
\text { that I should send a } \\
\text { report of concern }\end{array}$ & $\begin{array}{l}\text { totally disagree, } \\
\text { disagree, neither/nor, } \\
\text { agree, totally agree }\end{array}$ & & 4.45 & .673 & -1.326 & .072 & 2.985 & .143 \\
\hline \multirow[t]{5}{*}{ Capacity $\quad$ PBC } & & & $\begin{array}{l}\text { If I, during the coming } \\
12 \text { months, suspects } \\
\text { child abuse or neglect }\end{array}$ & & & & & & & & \\
\hline & $19^{b}$ & 1167 & $\begin{array}{l}\text { I am very unsure if I am } \\
\text { able to send a report of } \\
\text { concern }\end{array}$ & $\begin{array}{l}\text { totally disagree, } \\
\text { disagree, neither/nor, } \\
\text { agree, totally agree }\end{array}$ & .744 & 4.01 & .946 & -1.097 & .072 & 1.092 & .143 \\
\hline & 20 & 1168 & $\begin{array}{l}\text { I am absolutely } \\
\text { confident I can send a } \\
\text { report of concern }\end{array}$ & $\begin{array}{l}\text { totally disagree, } \\
\text { disagree, neither/nor, } \\
\text { agree, totally agree. }\end{array}$ & & 4.00 & .885 & -1.036 & .072 & 1.296 & .143 \\
\hline & 21 & 1167 & $\begin{array}{l}\text { I have full opportunity } \\
\text { to send a report of } \\
\text { concern }\end{array}$ & $\begin{array}{l}\text { totally disagree, } \\
\text { disagree, neither/nor, } \\
\text { agree, totally agree. }\end{array}$ & & 4.38 & .699 & -1.589 & .072 & 4.904 & .143 \\
\hline & $22^{b}$ & 1167 & $\begin{array}{l}\text { it would be difficult to } \\
\text { send a report of } \\
\text { concern }\end{array}$ & $\begin{array}{l}\text { totally disagree, } \\
\text { disagree, neither/nor, } \\
\text { agree, totally agree }\end{array}$ & & 3.60 & 1.057 & -.458 & .072 & -.571 & .143 \\
\hline \multirow[t]{3}{*}{ Autonomy } & & & $\begin{array}{l}\text { If } \mathrm{I} \text {, during the } \\
\text { coming } 12 \text { months, } \\
\text { suspects child abuse or } \\
\text { neglect }\end{array}$ & & & & & & & & \\
\hline & 23 & 1167 & $\begin{array}{l}\text { there are few outside } \\
\text { events that can prevent } \\
\text { me from sending a } \\
\text { report of concern }\end{array}$ & $\begin{array}{l}\text { totally disagree, } \\
\text { disagree, neither/nor, } \\
\text { agree, totally agree }\end{array}$ & & 3.66 & 1.026 & -.693 & .072 & .071 & .143 \\
\hline & 24 & 1168 & $\begin{array}{l}\text { I have complete control } \\
\text { over sending a report } \\
\text { of concern }\end{array}$ & $\begin{array}{l}\text { totally disagree, } \\
\text { disagree, neither/nor, } \\
\text { agree, totally agree }\end{array}$ & & 3.63 & .942 & -.451 & .072 & -.282 & .143 \\
\hline
\end{tabular}


Table 2 Descriptive statistics for RAA measurement model (Continued)

\begin{tabular}{|c|c|c|c|c|c|c|c|c|c|c|c|}
\hline \multirow[t]{2}{*}{ Latent factor } & \multirow[t]{2}{*}{ Item } & \multirow[t]{2}{*}{$\mathrm{N}$} & \multirow[t]{2}{*}{ Question } & \multirow{2}{*}{$\begin{array}{l}\text { Answers } \\
\text { Valued 1-5 (very } \\
\text { difficult = } 1 \text { - very } \\
\text { easy = 5) }\end{array}$} & \multirow{2}{*}{$\begin{array}{l}\text { Cronb. } \\
\text { alpha }\end{array}$} & \multicolumn{2}{|l|}{ Mean } & \multicolumn{2}{|c|}{ Skewness } & \multicolumn{2}{|l|}{ Kurtosis } \\
\hline & & & & & & Statistic & $\begin{array}{l}\text { Std. } \\
\text { dev }\end{array}$ & Statistic & Std.error & Statistic & Std.error \\
\hline & $25^{b}$ & 1167 & $\begin{array}{l}\text { sending a report of } \\
\text { concern is beyond my } \\
\text { control }\end{array}$ & $\begin{array}{l}\text { totally disagree, } \\
\text { disagree, neither/nor, } \\
\text { agree, totally agree }\end{array}$ & & 4.21 & .749 & -1.034 & .072 & 1.849 & .143 \\
\hline & $26^{\mathrm{a}}$ & 1166 & $\begin{array}{l}\text { It is entirely up to me } \\
\text { whether I will send a } \\
\text { report of concern or } \\
\text { not }\end{array}$ & $\begin{array}{l}\text { totally disagree, } \\
\text { disagree, neither/nor, } \\
\text { agree, totally agree. }\end{array}$ & & 3.64 & 1.154 & -.705 & .072 & -.373 & .143 \\
\hline \multirow[t]{4}{*}{ Intention } & 27 & 1155 & $\begin{array}{l}\text { In the next } 12 \text { months I } \\
\text { intend to send a report } \\
\text { of concern to the CWS } \\
\text { if I suspect child abuse } \\
\text { or neglect }\end{array}$ & $\begin{array}{l}\text { totally disagree, } \\
\text { disagree, neither/nor, } \\
\text { agree, totally agree }\end{array}$ & .759 & 4.38 & .859 & -2.099 & .072 & 5.592 & .144 \\
\hline & 28 & 1155 & $\begin{array}{l}\text { If I in the coming } 12 \\
\text { months suspect child } \\
\text { abuse or neglect, I will } \\
\text { send a report of } \\
\text { concern }\end{array}$ & $\begin{array}{l}\text { completely unsure, } \\
\text { unsure, neither/nor, } \\
\text { sure, completely sure }\end{array}$ & & 4.23 & .790 & -1.086 & .072 & 1.636 & .144 \\
\hline & 29 & 1155 & $\begin{array}{l}\text { If I during the next } 12 \\
\text { months gets suspicious } \\
\text { of child abuse or } \\
\text { neglect I want to send } \\
\text { a report of concern }\end{array}$ & $\begin{array}{l}\text { totally disagree, } \\
\text { disagree, neither/ } \\
\text { nor, agree, totally agree }\end{array}$ & & 4.47 & .685 & -1.568 & .072 & 4.150 & .144 \\
\hline & 30 & 1149 & $\begin{array}{l}\text { if you during the next } \\
12 \text { months is concerned } \\
\text { for a child (regarding } \\
\text { child abuse or neglect) } \\
\text { how unlikely or likely is } \\
\text { it that you will send a } \\
\text { report of concern? }\end{array}$ & $\begin{array}{l}\text { quite unlikely, unlikely, } \\
\text { neither/nor, likely, quite } \\
\text { likely }\end{array}$ & & 4.12 & .622 & -.304 & .072 & .534 & .144 \\
\hline
\end{tabular}

${ }^{a}$ Item 26 was deleted

${ }^{b}$ Items 19, 22 and 25 were negatively loaded, and their values were reversed

factors was supported by explorative factor/component analyses. Horn's Parallel analysis suggested six factors and an explorative factor analysis (geomin (oblique) rotation) gave generally good support for the modified six-factor solution. Increasing the number of factors to seven did furthermore not lead to separate capacity and autonomy factors as hypothesized by the original model. The reestimation of the correlated six-factor model (Model 2) also lacked an adequate fit to the data however, see Table 3.

Modification indices suggested some misfit in the model and that the model fit could be improved by allowing for correlated residuals between the items in the descriptive norm factor (item 9 with item 10, item 12 with item 13), the perceived behavioural control factor (item 20 with item 21) and the intention factor (item 27 with item 29). In addition, item 22 was cross-loaded on the experiential attitude factor in addition to the perceived behavioural control factor. Re-estimation of the modified six factor model (Model 3) provided an adequate fit, see Table 3 . The standardized factor loadings for the correlated six factor model (Model 3) revealed that all items, except one, loaded significantly $P<0.001$ on their respective latent variables, all with factor loadings $>0.300$. The exception was the autonomy item 26)

Table 3 Overall goodness of fit indices for the RAA measurement model (model 1-4) and full structural model (model 5)

\begin{tabular}{llllll}
\hline Fit indices & Model 1 & Model 2 & Model 3 & Model 4 & Model 5 \\
\hline$X^{2}$ & 1875.570 & 1902.915 & 1136.095 & 1071.041 & 1071.041 \\
DF & $384, P<0.001$ & $390, P<0.001$ & $385, P<0.001$ & $357, P<0.001$ & $357, P<0.001$ \\
RMSEA & 0.057 & 0.057 & 0.041 & 0.041 & 0.041 \\
$90 \%$ Cl for RMSEA & $0.055-0.060$ & $0.055-0.060$ & $0.038-0.043$ & $0.038-0.044$ & $0.038-0.044$ \\
CFI & 0.884 & 0.882 & 0.941 & 0.943 & 0.943 \\
SRMR & 0.053 & 0.054 & 0.046 & 0.046 & 0.046 \\
\hline
\end{tabular}


("If I, during the coming twelve months, suspects child abuse or neglect, it is entirely up to me whether I will send a report of concern or not."). This item was loaded 0.100 on the merged perceived behavioural control factor. Due to the low factor loading, the autonomy item 26 was dropped, and the model was re-estimated.

The final modified measurement model (Model 4) achieved an adequate fit, see Table 3 . As shown in Table 4 , all items loaded significantly $(p<.001)$ and in the expected direction on their respective latent variables. The statistically significant standardized loadings ranged from 0.332 to 0.894 . All inter-factor correlations were below the cut-off point of 0.850 for the standardized correlation coefficient. The standardized correlation coefficient ranged from 0.120 , SE $0.035 P=0.001$ for injunctive norms and experiential attitudes to 0.679 , SE $0.037 P<0.001$ for intention and perceived behavioural control, indicating discriminant validity between the latent variables [55].

Configural invariance across the genders was supported, as Model 4 had an adequate fit for both females $\left(\mathrm{X}^{2}=909.080\right.$, d.f. $=357, P<0.001$, RMSEA 0.042, 90\% CI for RMSEA 0.038-0.045, CFI $=0.944$, SRMR $=0.049$ ) and males $\left(X^{2}=597.199\right.$, d.f. $=357, P<0.001$, RMSEA $0.055,90 \%$ CI for RMSEA 0.048-0.063, CFI $=0.908$, SRMR $=0.061$ ). Metric invariance (equal factor loading) was also obtained for each factor (results not shown), thus demonstrating that the size of the predictive paths could be compared between men and women in step 2 .

\section{Step 2. The full structural equation model}

Based on the adequate fit of the six-factor model (Model 4), a full structural equation model was conducted to estimate the fit of the structural model and the relationships among the latent constructs, see Fig. 2. The full structural equation model (Model 5) achieved a good model fit, see Table 3. The analysis revealed that having an instrumental attitude (standardized beta $=0.377$, SE 0.047, $P<0.001$ ) and perceived behavioural control (Standardized beta $=$ 0.364, SE 0.049, $\mathrm{P}<0.001$ ) were the strongest predictors of intention, followed by descriptive norms (standardized beta $=0.125$, SE $0.043, P<0.01$ ), injunctive norms (standardized beta $=0.095$, SE 0.040, $P<0.05$ ) and experiential attitudes (standardized beta $=0.084$, SE 0.036, $P<0.05$ ). The full structural equation model (Model 5) revealed that the modified RAA model (capacity and autonomy merged) could explain $63.6 \%$ of the variance in the behavioural intention $\left(R^{2}=0.636\right.$, SE $\left.0.050 P<0.001\right)$.

Multi-group analyses of the full structural equation model did support the invariant regression paths across gender, as the fit of the model did not significantly worsen when each of the predictive paths were constrained to be equal compared to when they were free to vary across the genders, see Table 5 .
Table 4 Standardized factor loadings for the RAA measurement model 4

\begin{tabular}{|c|c|c|c|c|}
\hline Latent factor & & Item & Stand. factor loadings & Std. error \\
\hline \multicolumn{5}{|c|}{ Experiential attitude } \\
\hline & & 1 & 0.817 & 0.017 \\
\hline & & 2 & 0.802 & 0.017 \\
\hline & & 3 & 0.657 & 0.025 \\
\hline & & 4 & 0.627 & 0.025 \\
\hline & & 22 & 0.369 & 0.033 \\
\hline \multicolumn{5}{|c|}{ Instrumental attitude } \\
\hline & & 5 & 0.695 & 0.036 \\
\hline & & 6 & 0.718 & 0.020 \\
\hline & & 7 & 0.802 & 0.019 \\
\hline & & 8 & 0.753 & 0.020 \\
\hline \multicolumn{5}{|c|}{ Descriptive norm } \\
\hline & & 9 & 0.762 & 0.019 \\
\hline & & 10 & 0.732 & 0.021 \\
\hline & & 11 & 0.866 & 0.015 \\
\hline & & 12 & 0.810 & 0.020 \\
\hline & & 13 & 0.763 & 0.023 \\
\hline \multicolumn{5}{|c|}{ Injunctive norm } \\
\hline & & 14 & 0.856 & 0.018 \\
\hline & & 15 & 0.894 & 0.014 \\
\hline & & 16 & 0.825 & 0.020 \\
\hline & & 17 & 0.841 & 0.018 \\
\hline & & 18 & 0.767 & 0.026 \\
\hline \multirow{5}{*}{\multicolumn{2}{|c|}{ Capacity }} & & & \\
\hline & & $19^{b}$ & 0.637 & 0.037 \\
\hline & & 20 & 0.696 & 0.036 \\
\hline & & 21 & 0.466 & 0.049 \\
\hline & & $22^{b}$ & 0.413 & 0.038 \\
\hline \multicolumn{5}{|l|}{ Autonomy } \\
\hline & & 23 & 0.332 & 0.038 \\
\hline & & 24 & 0.629 & 0.024 \\
\hline & & $25^{b}$ & 0.459 & 0.035 \\
\hline \multirow{5}{*}{\multicolumn{2}{|c|}{ Intention }} & a & & \\
\hline & & 27 & 0.516 & 0.041 \\
\hline & & 28 & 0.785 & 0.027 \\
\hline & & 29 & 0.683 & 0.034 \\
\hline & & 30 & 0.636 & 0.030 \\
\hline
\end{tabular}

altem 26 was deleted

bltems 19, 22 and 25 were negatively loaded, and their values were reversed All loadings were significant at $P<0.001$

\section{Discussion}

To our knowledge, the present study is the first to explain the intentions of dental health personnel regarding 


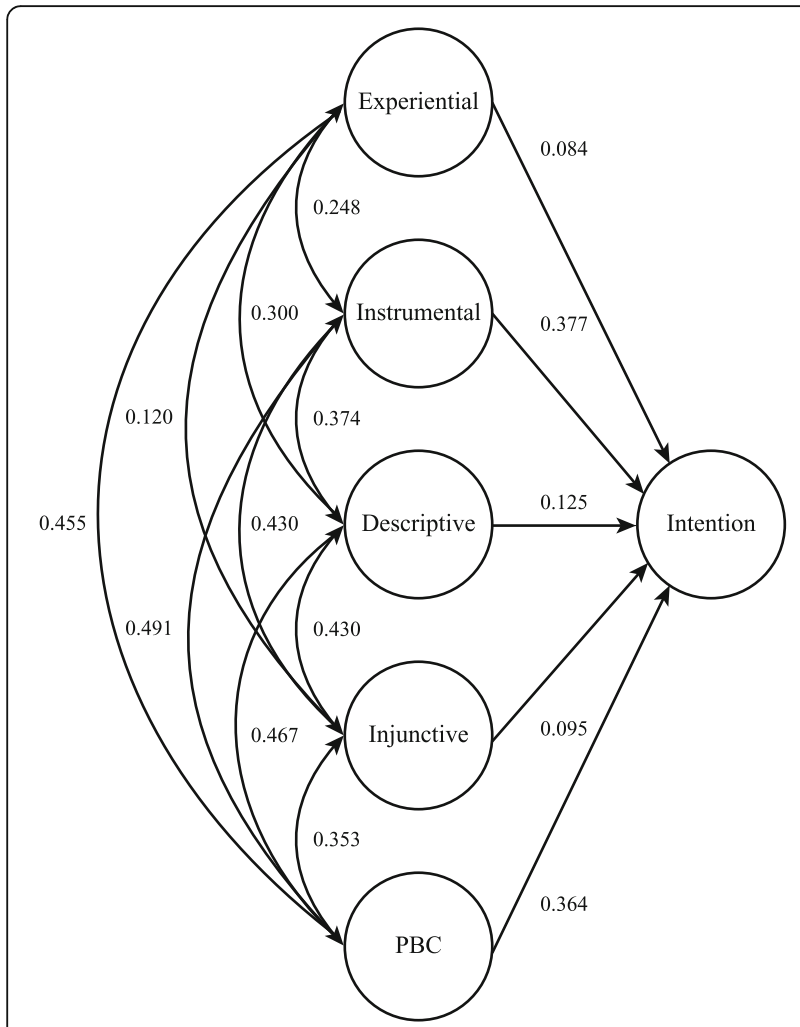

Fig. 2 SEM model 5 (Standardized coefficients)

reporting suspected child maltreatment using a sociocognitive theoretical framework (RAA).

The findings of the present study provided support for the utility of the RAA across males and females in predicting dental health personnel's intention to report suspicion of child maltreatment to the CWS. The modified RAA model, demonstrated a good fit to the data, and explained $63.6 \%$ of the variance in the behavioural intentions. This suggests that the RAA is a well-functioning theory in order to predict and explain dental health personnel's professional reporting behaviour. In accordance with the RAA, we found that the instrumental attitude (i.e., cognitive aspects of behavioural beliefs), perceived behavioural control (i.e., perception of control and capacity to report suspicion of child maltreatment), descriptive norm (i.e., perceptions of what others do), injunctive norm (i.e., the perceived social approval of others) and experiential attitude (i.e., affective aspects of behavioural beliefs) were, in descending order of importance, significant predictors of intended reporting behaviour. The present findings were consistent with a previous review using the RAA to predict risk- and protective healthrelated behaviours, implying that the RAA also can be used to predict reporting behaviour [41]. Although the RAA and the original TPB differ in terms of the number of predictors of behavioural intention, the explained variance in behavioural intention obtained in this study (63.6\%) compared well with the those reported in studies using the TPB to predict health care personnel's professional behaviour $[44,57,58]$. In meta-analyses, the RAA and the TPB accounted for 59 and $44 \%$ of the variance in the behavioural intentions, respectively [34, 41]. Altogether, the findings and explained variance indicate that the RAA functions well in order to assess and predict reporting intention among dental health personnel.

In the present study, the instrumental attitude (i.e., cognitive aspects of behavioural beliefs) emerged as the strongest determinant of intended reporting behaviour. This implies that the decision to report was strongly based on the anticipated benefits of performing that behaviour, for the child and society. This is consistent with previous TPB-based studies focusing dental personnel's professional behaviour, which found that attitudes are a strong predictor of intensions related to fissure sealing and oral radiographs $[44,45,47]$. A recent TPB study predicting dentists' intended delivery of a variety of prevention activities in regard to diet, alcohol and smoking, revealed that attitudes were an important predictor of their intentions to perform preventive behaviours [46]. Experiential attitudes (i.e., affective aspects of behavioural beliefs) turned out to be the weakest predictor of reporting intention. This suggests that even though reporting could be demanding or challenging, it has only a minor influence on dental health personnel's reporting intention. This finding was at odds with previous studies using RAA, for which experiential attitudes have been found to be one of the main predictors of health-related intention and behaviour [41, 59-61]. Nevertheless, the relative effect of the theoretical constructs is expected to vary according to the type of behaviour and the participants under study [62]. The professional behaviour

Table 5 Test for invariance of the predictive paths across gender

\begin{tabular}{|c|c|c|c|c|}
\hline Equality constraint & $\Delta$ Satorra-Bentler Scaled Chi Square & $\Delta \mathrm{df}$ & Probability & $\Delta \mathrm{CFI}$ \\
\hline Instrumental attitude $\rightarrow$ Intention & $0.73+$ & 1 & 0.39 & $<0.01$ \\
\hline Experiential attitude $\rightarrow$ Intention & 1.79 & 1 & 0.18 & $<0.01$ \\
\hline Injunctive norm $\rightarrow$ Intention & 0.16 & 1 & 0.69 & $<0.01$ \\
\hline Descriptive norm $\rightarrow$ Intention & 0.36 & 1 & 0.55 & $<0.01$ \\
\hline Perceived behavioural control $\rightarrow$ Intention & 0.34 & 1 & 0.56 & $<0.01$ \\
\hline
\end{tabular}

+ Worsening of the fit when the path was constrained to be equal compared to when it was free to vary across gender 
investigated in this study might be categorized as a detection behaviour which is suggested to differ from riskand protective health behaviours [59]. Consistent with this reasoning, Conner et al. (2015) provided empirical support for the predictive effect of affective or experiential attitudes on risk- and protective health-related behaviours, whereas no such effects on the category of detection behaviour were seen.

In accordance with a meta analytical review of studies using the RAA [41], PDHP's perception of control and capacity $(\mathrm{PBC})$ turned out to be a strong predictor of the intended reporting behaviour. This suggests that not only beliefs about the positive consequences of reporting behaviour but also beliefs about difficulties and facilitating aspects associated with reporting should be targeted in educational messages that aim to enhance the intended reporting behaviour. The strong effect of perceived behavioural control is consistent with the results of previous studies that have identified actual barriers towards reporting suspected child maltreatment among professionals required to report suspected abuse, emphasizing a lack of knowledge about the signs of abuse and referral procedures in addition to the negative consequences for the patient, as important barriers [15, 19, 63].

Both descriptive (i.e., perceptions of what others do) and injunctive (i.e., the perceived social approval of others) norms turned out to be independent, albeit rather weak predictors of dental health personnel's' intended reporting behaviour. This suggests that dentists and dental hygienists are guided not only by normative expectations from others but also by what significant others actually do regarding reporting behaviour. As mandated through the Norwegian Health Personnel Act, normative beliefs may have connotations to dental health personnel's moral obligations, responsibilities or personal standards in relation to reporting child maltreatment. Meta analytical reviews have also shown that descriptive norms add to the prediction of health related behaviours independent of the attitudes, subjective norms and perceived behavioural controls [64]. Consistent with the results of the present study, Godin et al. (1999) found normative beliefs to be a predictor of dentists' intention to provide dental care to HIV+/AIDS infected patients [58]. Furthermore, in studies using RAA and TPB, descriptive and injunctive norms are often observed as weak or non- significant predictors of intention. Importantly, injunctive norms have traditionally turned out to be weaker predictors of behavioural intention than attitudes and perceived behavioural controls [27].

The present findings should be interpreted in the context of the strengths and limitations of this study. Being cross-sectional and relying on self-reports, conclusions about cause-and-effect relationships are difficult to draw, and there is a risk of reporting bias as respondents might be those who are interested in the topic. It is also important to be aware that some behaviors might be driven differently between cultures. Thus, one should be careful to extrapolate the findings to other cultures and populations. Another limitation is related to intentions being the final dependent variable and not actual reporting behaviour, as hypothesized by the RAA. Future studies should therefore have a longitudinal design and investigate both intended and actual reporting behaviour. However, the present study was national and included a census of public dentists and dental hygienists in Norway. Moreover, the high $78 \%$ response rate [13] reduces the possibility that missing responses have seriously biased the collected data on the intended reporting behaviour [65, 66], although social desirability might have biased the answers. In addition, the present study utilizes a powerful multivariable statistical technique testing the RAA model overall rather than the coefficients individually [67]. In contrast to traditional multivariate methods, SEM is well fit to address complex behaviours, as it allows for the simultaneous analysis of both the observed and latent variables, their relationships and the model fit. Furthermore, SEM also accounts for measurement errors by providing estimates of error variance parameters while simultaneously estimating the modelled path coefficients [68]. The application of SEM improves the conceptual understanding of the RAA as a structural and measurement model.

Although information about the performance of the RAA across age groups and other socio-demographic characteristics of the study population would have been of interest, the present multi-group analysis by gender strengthened our findings to some extent. The present findings have implications for dentistry and educational institutions, providing guidance for the development of future interventions.

The study suggests relatively strongly that educational messages intending to strengthen dental health personnel's intention to report suspected maltreatment would benefit from an emphasis on the benefits of such reports for the child, its family and the society at large. There should also be an emphasis on the specifics about how to make such a report and that dental health personnel are capable and permitted to do this. Moreover, the reporting intention might be further strengthen by educational messages focusing on the normative aspects regarding reporting of child maltreatment, in terms of clarifying that reporting is socially accepted, expected and the right thing to do. In addition one should acknowledge that reporting often is hard and demanding but useful.

\section{Conclusions}

This study provided support for the utility of a modified RAA model across gender in predicting dental health 
personnel's intention to report suspected child maltreatment to the CWS. Norwegian PDHP's intention to report suspected child maltreatment was mostly based on considerations of likely positive cognitive consequences of performance, required resources and potential obstacles, as well as normative expectations and affective attitude, in that order. To strengthen reporting intention among dental personnel, this study suggests educators should focus on the value and positive consequences of reporting, the resources available and how to overcome obstacles; attention to normative expectations and individuals' feelings about reporting may also be helpful.

Emphasizing these factors in the future training and education of dental health personnel might strengthen the reporting intention of suspected child maltreatment and contribute to reduce the gap between suspicion and reporting. Future studies should incorporate a measure of observed behaviour. A detailed analysis of the belief structure underlying attitudes, norms and perceived behavioural control may extend the applicability of the RAA model.

\section{Additional file}

Additional file 1: Tannhelse og barnevern - samhandling til beste for barnet. Questionnaire regarding dental personnel's suspicion of child maltreatment and reporting to child welfare services. The questionnaire was sent to dental hygienists and dentists in the public dental health service in Norway 2014. The questionnaire is previously published in Brattabø et al. 2018 [14]. (PDF 254 kb)

\section{Abbreviations \\ CFI: Comparative Fit Index; CWS: Child Welfare Service; GEE: Generalized Estimating Equations; MLR: Maximum Likelihood Estimator with Robust Standard Errors; NSD: Norwegian Social Science Data Services; PBC: Perceived Behavioural Control; PDHP: Public Dental Health Personnel; PDHS: Public Dental Health Service; RAA: Reasoned Action Approach; RMSEA: Root Mean Square Error of Approximation; SEM: Structural equation modelling; SRMR: Standardized Root Mean Squared Residual; TPB: Theory of Planned Behaviour}

\section{Acknowledgments}

The authors would like to express their thankfulness to the public dental health service in Norway for making this study possible.

\section{Authors' contributions}

IVB: Contributed to the study design, was the main contributor to the data collection, carried out the statistical analysis and was the main contributor to writing the manuscript. RB: Contributed to the study design, data collection and writing of the manuscript. KB: Contributed to the study design, statistical analysis and writing of the manuscript. ANÅ: Contributed to the study design, statistical analysis and writing of the manuscript. All authors read and approved the final manuscript.

\section{Funding}

This study did not receive any funding from agencies in the public, commercial, or not-for-profit sector.

\section{Availability of data and materials}

The dataset will not be made available, as more articles are to be published based on this dataset.

\section{Ethics approval and consent to participate}

The Ombudsman, Norwegian Social Science Data Services (NSD), approved and registered the survey (Reference number: 40581/4/LH/LR). NSD was responsible for the questionnaire distribution and the data collection. All participants received an email explaining the purpose of the study and informing them that all participation in this study was voluntary. The email included a link to the electronic questionnaire, which contained an informed consent form.

The Regional Etichs Committee (REK nord) ruled that no formal ethics approval was required in this particular case (Reference number: 2013/2131/REK nord).

\section{Consent for publication \\ Not applicable.}

\section{Competing interests}

The authors declare that they have no competing interests.

\section{Author details}

${ }^{1}$ Oral Health Centre of Expertise in Western Norway, Hordaland, Pb. 2354 Møllendal, 5867 Bergen, Norway. ${ }^{2}$ Department of Health Promotion and Development, Faculty of Psychology, University of Bergen, Pb. 7807, 5020 Bergen, Norway. ${ }^{3}$ Department of Clinical Dentistry, Faculty of Medicine, University of Bergen, Norway, Pb. 7804, 5020 Bergen, Norway. ${ }^{4}$ Regional Centre for Child and Youth Mental Health and Child Welfare, NORCE Norwegian Research Centre, Bergen, Norway, Pb 7810, 5020 Bergen, Norway.

Received: 6 February 2018 Accepted: 8 July 2019

Published online: 22 July 2019

References

1. Norman RE, Byambaa M, De R, Butchart A, Scott J, Vos T. The long-term health consequences of child physical abuse, emotional abuse, and neglect: a systematic review and meta-analysis. PLoS Med. 2012;9:1-31 http://www. ncbi.nlm.nih.gov/pmc/articles/PMC3507962/pdf/pmed.1001349.pdf.

2. Gilbert R, Widom CS, Browne K, Fergusson D, Webb E, Janson S. Burden and consequences of child maltreatment in high-income countries. Lancet. 2009;373:68-81. https://doi.org/10.1016/S0140-6736(08)61706-7.

3. Nemeroff CB. Paradise lost: the neurobiological and clinical consequences of child abuse and neglect. Neuron. 2016;89:892-909.

4. Hein TC, Monk CS. Research review: neural response to threat in children, adolescents, and adults after child maltreatment - a quantitative meta-analysis. J Child Psychol Psychiatry. 2017;58:222-30. https://doi.org/10.1111/jcpp.12651.

5. Felitti VJ, Anda RF, Nordenberg D, Williamson DF, Spitz AM, Edwards V, et al. Relationship of childhood abuse and household dysfunction to many of the leading causes of death in adults: the adverse childhood experiences (ACE) study. Am J Prev Med. 1998;14:245-58. https://doi.org/10.1016/S0749-3 797(98)00017-8.

6. World Health Organization. European report on preventing child maltreatment. Denmark: 2013.

7. Anda RF, Felitti VJ, Bremner JD, Walker JD, Whitfield C, Perry BD, et al. The enduring effects of abuse and related adverse experiences in childhood. Eur Arch Psychiatry Clin Neurosci. 2006;256:174-86.

8. Green JG, McLaughlin KA, Berglund PA, Gruber MJ, Sampson NA, Zaslavsky AM, et al. Childhood adversities and adult psychiatric disorders in the national comorbidity survey replication I: associations with first onset of DSM-IV disorders. Arch Gen Psychiatry. 2010;67:113-23.

9. Poulton R, Moffitt T, Silva P. The Dunedin multidisciplinary health and development study: overview of the first 40 years, with an eye to the future. Soc Psychiatry Psychiatr Epidemiol. 2015;50:679-93. https://doi.org/10.1007/ s00127-015-1048-8.

10. The Health Personnel Act. Available from: https://lovdata.no/dokument/NL/ lov/1999-07-02-64?q=helsepersonell\%20loven Accessed: 02 Dec 2016.

11. The Public Dental Health Service Act. Available from: https://lovdata.no/ dokument/NL/lov/1983-06-03-54 Accessed: 02 Dec 2016.

12. Statistics Norway. 2018. Available from: www.ssb.no/en/statistikkbanken accessed: 25 Oct 2018.

13. Brattabø IV, Iversen AC, Åstrøm AN, Bjørknes R. Experience with suspecting child maltreatment in the Norwegian public dental health services, a national survey. Acta Odontol Scand. 2016;74:626-32.

14. Brattabø IV, Bjørknes R, Åstrøm AN. Reasons for reported suspicion of child maltreatment and responses from the child welfare-a cross-sectional 
study of Norwegian public dental health personnel. BMC Oral Health. 2018;18:29.

15. Uldum B, Christensen HN, Welbury R, Haubek D. How Danish dentists and dental hygienists handle their role in child abuse and neglect matters Acta Odontol Scand. 2017;75:332-7.

16. Dalledone M, Paola APB, Correr GM, Pizzatto E, JFd S, Losso EM. Child abuse: perception and knowledge by public health dentistry teams in Brazil. Braz J Oral Sci. 2015;14:224-9.

17. Newcity A, Ziniel S, Needleman H. Part 2: Abuse. J Mass Dent Soc. 2011;60:24-7 http://www.ncbi.nlm.nih.gov/pubmed/22308606.

18. Newcity A, Ziniel S, Needleman H. Part 3: neglect. J Mass Dent Soc. 2011;60:28-31 http://www.ncbi.nlm.nih.gov/pubmed/22308607.

19. Harris CM, Welbury R, Cairns AM. The Scottish dental practitioner's role in managing child abuse and neglect. Br Dent J. 2013;214:1-5. https://doi. org/10.1038/sj.bdj.2013.435

20. Tilvawala D, Murray C, Farah R, Broadbent JM. New Zealand dental therapists' beliefs regarding child maltreatment. Aust N Z J Public Health. 2014;38:480-4. https://doi.org/10.1111/1753-6405.12238.

21. Uldum B, Christensen HN, Welbury R, Poulsen S. Danish dentists' and dental hygienists' knowledge of and experience with suspicion of child abuse or neglect. Int J Paediatr Dent. 2010;20:361-5. https://doi.org/10.1111/ j.1365-263X.2010.01070.x.

22. Laud A, Gizani S, Maragkou S, Welbury R, Papagiannoulis L. Child protection training, experience, and personal views of dentists in the prefecture of Attica. Greece Int J Paediatr Dent. 2013;23:64-71.

23. Goebbels AFG, Nicholson JM, Walsh K, De Vries H. Teachers' reporting of suspected child abuse and neglect: behaviour and determinants. Health Educ Res. 2008;23:941-51. https://doi.org/10.1093/her/cyn030.

24. Feng JY, Wu YWB. Nurses' intention to report child abuse in Taiwan: a test of the theory of planned behavior. Res Nurs Health. 2005;28:337-47.

25. Christodoulou A-D, Abakoumkin G, Tseliou E, editors. Teachers' Intention to Report Child Maltreatment: Testing Theoretically Derived Predictions. Child \& Youth Care Forum; 2019: Springer.

26. Ajzen I. The theory of planned behavior. Organ Behav Hum Decis Process. 1991;50:179-211.

27. Armitage CJ, Conner M. Efficacy of the theory of planned behaviour: a meta-analytic review. Br J Soc Psychol. 2001;40:471-99. https://doi.org/ 10.1348/014466601164939.

28. Hagger MS, Chatzisarantis NL, Biddle SJ. A meta-analytic review of the theories of reasoned action and planned behavior in physical activity: predictive validity and the contribution of additional variables. Journal of sport and exercise psychology. 2002;24:3-32

29. Albarracin D, Johnson BT, Fishbein M, Muellerleile PA. Theories of reasoned action and planned behavior as models of condom use: a meta-analysis. Psychol Bull. 2001;127:142-61.

30. McDermott MS, Oliver M, Simnadis T, Beck E, Coltman T, Iverson D, et al. The theory of planned behaviour and dietary patterns: a systematic review and meta-analysis. Prev Med. 2015;81:150-6.

31. Webb TL, Sheeran P. Does changing behavioral intentions engender behavior change? A meta-analysis of the experimental evidence. Psychol Bull. 2006;132:249-68.

32. Sheeran P. Intention — behavior relations: a conceptual and empirical review. Eur Rev Soc Psychol. 2002;12:1-36.

33. Ajzen I, Madden TJ. Prediction of goal-directed behavior: attitudes, intentions, and perceived behavioral control. J Exp Soc Psychol. 1986;22:453-74. https://doi.org/10.1016/0022-1031(86)90045-4.

34. McEachan R, Conner M, Taylor NJ, Lawton RJ. Prospective prediction of health-related behaviours with the theory of planned behaviour: a metaanalysis. Health Psychol Rev. 2011;5:97-144.

35. Hagger M, Chatzisarantis N. First- and higher-order models of attitudes, normative influence, and perceived behavioural control in the theory of planned behaviour. The British Journal of Social Psychology. 2005;44:513-35. https://doi.org/10.1348/014466604X16219.

36. Perugini $\mathrm{M}$, Bagozzi RP. The role of desires and anticipated emotions in goal-directed behaviours: broadening and deepening the theory of planned behaviour. Br J Soc Psychol. 2001;40:79-98. https://doi.org/10.1348/0144666 01164704

37. Rivis A, Sheeran P, Armitage CJ. Expanding the affective and normative components of the theory of planned behavior: a Meta-analysis of anticipated affect and moral norms. J Appl Soc Psychol. 2009;39:2985-3019. https://doi.org/10.1111/j.1559-1816.2009.00558.x.
38. Fishbein M, Aizen I. Predicting and changing behavior: the reasoned action approach. New York: Psychology Press; 2010.

39. Ajzen I. Martin Fishbein's legacy: the reasoned action approach. The Annals of the American Academy of Political and Social Science. 2012;640:11-27.

40. Conner M, Sparks P. Theory of planned behaviour and health behaviour. In: Conner $\mathrm{M}$, Normann $\mathrm{P}$, editors. Predicting health behaviour 2ed. England: Open university Press; 2005. p. 170-222.

41. McEachan R, Taylor NJ, Harrison R, Lawton R, Gardner P, Conner M. Meta-analysis of the reasoned action approach (RAA) to understanding health behaviors. Ann Behav Med. 2016;50:592-612. https://doi.org/10.1007/ s12160-016-9798-4.

42. Ajzen I. Perceived behavioral control, self-efficacy, locus of control, and the theory of planned behavior. J Appl Soc Psychol. 2002;32:665-83.

43. Millstein SG, Krantz DS. Utility of the theories of reasoned action and planned behavior for predicting physician behavior: a prospective analysis. Health Psychol. 1996;15:398-402. https://doi.org/10.1037/0278-6133.15.5.398.

44. Bonetti D, Johnston M, Clarkson J, Grimshaw J, Pitts N, Eccles M, et al. Applying psychological theories to evidence-based clinical practice: identifying factors predictive of placing preventive fissure sealants. Implement Sci. 2010;5:1-14. https://doi.org/10.1186/1748-5908-5-25.

45. Bonettia D, Pittsa NB, Ecclesb M, Grimshawc J, Johnstond M, Steenb N, et al. Applying psychological theory to evidence-based clinical practice: identifying factors predictive of taking intra-oral radiographs.(report). Soc Sci Med. 2006;63:1889-99.

46. Yusuf H, Kolliakou A, Ntouva A, Murphy M, Newton T, Tsakos G, et al. Predictors of dentists' behaviours in delivering prevention in primary dental care in England: using the theory of planned behaviour. BMC Health Serv Res. 2016;16:1-7. https://doi.org/10.1186/s12913-016-1293-x.

47. Bonetti $\mathrm{D}$, Johnston $\mathrm{M}$, Clarkson J, Turner S. Applying multiple models to predict clinicians' behavioural intention and objective behaviour when managing children's teeth. Psychol Health. 2009;24:843-60. https://doi.org/ 10.1080/08870440802108918

48. Chen FF, Judd CM. What happens if we compare chopsticks with forks? The impact of making inappropriate comparisons in cross-cultural research. J Pers Soc Psychol. 2008;95:1005-18. https://doi.org/10.1037/a0013193.

49. Mplus. Chi-Square Difference Testing Using the Satorra-Bentler Scaled Chi-Square: Muthen \& Muthen; 2017 [cited 2017 20.09.2017]. Available from: http://www.statmodel.com/chidiff.shtml Accessed: 20 Sept 2017.

50. Meade AW, Johnson EC, Braddy PW, Zedeck S. Power and sensitivity of alternative fit indices in tests of measurement invariance. J Appl Psychol. 2008;93:568-92. https://doi.org/10.1037/0021-9010.93.3.568.

51. Hooper D, Coughlan J, Mullen M. Structural equation modelling: guidelines for determining model fit. Electron J Bus Res Methods. 2008;6:53-60.

52. Hu L, Bentler PM. Cutoff criteria for fit indexes in covariance structure analysis: conventional criteria versus new alternatives. Struct Equ Model. 1999;6:1-55.

53. Enders CK, Bandalos DL. The relative performance of full information maximum likelihood estimation for missing data in structural equation models. Struct Equ Model. 2001;8:430-57. https://doi.org/10.1207/S1532 8007SEM0803_5.

54. Schafer JL, Graham JW, West SG. Missing data: our view of the state of the art. Psychol Methods. 2002;7:147-77. https://doi.org/10.1037/1082-989X.7.2.147.

55. Brown TA. Confirmatory factor analysis for applied research. 2 ed. New York: Guilford Press; 2015. 461 p.

56. Grewal $\mathrm{R}$, Cote JA, Baumgartner $\mathrm{H}$. Multicollinearity and measurement error in structural equation models: implications for theory testing. Mark Sci. 2004;23:519-29.

57. Godin G, Bélanger-Gravel A, Eccles M, Grimshaw J. Healthcare professionals' intentions and behaviours: a systematic review of studies based on social cognitive theories. Implement Sci. 2008;3:1-12.

58. Godin G, Naccache H, Brodeur JM, Alary M. Understanding the intention of dentists to provide dental care to HIV+ and AIDS patients. Community Dent Oral Epidemiol. 1999;27:221-7.

59. Conner M, McEachan R, Taylor N, O'Hara J, Lawton R. Role of affective attitudes and anticipated affective reactions in predicting health behaviors. Health Psychol. 2015;34:642-52.

60. Lawton R, Conner M, Parker D. Beyond cognition: predicting health risk behaviors from instrumental and affective beliefs. Health Psychol. 2007;26:259-67.

61. Lawton R, Conner M, McEachan R. Desire or reason: predicting health behaviors from affective and cognitive attitudes. Health Psychol. 2009;28:56-65. 
62. Ajzen I, Fishbein M. Understanding attitudes and predicting social behavior. Upper Saddle River, N.J: Prentice-Hall; 1980.

63. Alvarez KM, Kenny MC, Donohue B, Carpin KM. Why are professionals failing to initiate mandated reports of child maltreatment, and are there any empirically based training programs to assist professionals in the reporting process? Aggress Violent Behav. 2004;9:563-78. https://doi.org/10.1016/ j.avb.2003.07.001.

64. Rivis A, Sheeran P. Descriptive norms as an additional predictor in the theory of planned behaviour: a meta-analysis. A Journal for Diverse Perspectives on Diverse Psychological Issues. 2003;22:218-33. https://doi.org/10.1007/s12144-003-1018-2.

65. McLeod CC, Klabunde CN, Willis GB, Stark D. Health care provider surveys in the United States, 2000-2010. Eval Health Prof. 2013;36:106-26. https://doi.org/10.1177/0163278712474001.

66. Funkhouser E, Vellala K, Baltuck C, Cacciato R, Durand E, McEdward D, et al. Survey methods to optimize response rate in the National Dental Practice-Based Research Network. Eval Health Prof. 2017;40:332-58. https://doi.org/10.1177/0163278715625738.

67. Byrne BM. Structural equation modeling with Mplus : basic concepts, applications, and programming. New York: Routledge; 2012.

68. Hair JF, Black WC, Babin BJ, Anderson RE, Tatham RL. Multivariate data analysis: Prentice Hall; Upper Saddle River, NJ; 1998.

\section{Publisher's Note}

Springer Nature remains neutral with regard to jurisdictional claims in published maps and institutional affiliations.

Ready to submit your research? Choose BMC and benefit from:

- fast, convenient online submission

- thorough peer review by experienced researchers in your field

- rapid publication on acceptance

- support for research data, including large and complex data types

- gold Open Access which fosters wider collaboration and increased citations

- maximum visibility for your research: over $100 \mathrm{M}$ website views per year

At $\mathrm{BMC}$, research is always in progress.

Learn more biomedcentral.com/submissions 